\title{
Miranda
}

Revue pluridisciplinaire du monde anglophone /

Multidisciplinary peer-reviewed journal on the English-

speaking world

5 | 2011

South and Race / Staging Mobility in the United States

\section{Allan Ingram, Stuart Sim, Clark Lawlor, Richard Terry, John Baker and Leigh Wetherall-Dickson, Melancholy Experience in the Long Eighteenth Century}

Hélène Dachez

\section{OpenEdition}

\section{Journals}

Electronic version

URL: http://journals.openedition.org/miranda/2650

DOI: $10.4000 /$ miranda.2650

ISSN: 2108-6559

\section{Publisher}

Université Toulouse - Jean Jaurès

\section{Electronic reference}

Hélène Dachez, "Allan Ingram, Stuart Sim, Clark Lawlor, Richard Terry, John Baker and Leigh WetherallDickson, Melancholy Experience in the Long Eighteenth Century", Miranda [Online], 5 | 2011, Online since 29 November 2011, connection on 16 February 2021. URL: http://journals.openedition.org/miranda/ 2650 ; DOl: https://doi.org/10.4000/miranda.2650

This text was automatically generated on 16 February 2021.

\section{c)}

Miranda is licensed under a Creative Commons Attribution-NonCommercial-NoDerivatives 4.0

International License. 


\title{
Allan Ingram, Stuart Sim, Clark Lawlor, Richard Terry, John Baker and Leigh Wetherall-Dickson, Melancholy Experience in the Long Eighteenth Century
}

\author{
Hélène Dachez
}

\section{REFERENCES}

Allan Ingram, Stuart Sim, Clark Lawlor, Richard Terry, John Baker and Leigh WetherallDickson, Melancholy Experience in the Long Eighteenth Century (Basingstoke : Palgrave Macmillan, 2011), ix + 246 p, ISBN 978-0-230-24631-7

1 Through the wide corpus it focuses on, this remarkable volume (one introduction and six chapters) aims at answering the following question: "what was depression like before depression existed as a standardized medical concept with a recognizable cluster of symptoms?" (2). The contributors explore the conditions, experience, discourse and representation of melancholy in the long eighteenth century from various perspectives-medical, philosophical, social and literary-and enable the reader to enjoy a thorough analysis of what melancholy meant and how it was considered at the time. Focusing on the "question of continuity and discontinuity" (2), it also offers a valuable insight into what melancholy means today.

2 The introduction by Allan Ingram and Stuart Sim (1-24) appositely focuses on the "medical and cultural inheritances for eighteenth-century melancholy" (3). It establishes valuable links between melancholy and the novel of sensibility-with a focus on "sympathetic attitudes towards those in low spirits" (13)-and draws attention to the importance of religion, and how melancholy people were regarded and treated 
by physicians. The various works mentioned there illustrate the wide range of sources to be found in all six chapters: medical treatises, literary items, mainly novels and poems, and criticism, which make the volume a highly valuable and innovative ensemble.

In Chapter 1 ("Fashionable Melancholy", 25-53) Clark Lawlor, who defines this very adaptable and even unstable disease in relation to hypochondria, the spleen, the vapours, and hysteria (27-28) and whose various degrees and types he analyses, offers enlightening explanations to account for the main paradox of melancholy in the long eighteenth century: why depressive states were viewed as positive, or even desirablealongside negative, "normal" appreciations of the disease. He also skilfully analyses the links between melancholy and creative genius (a notion inherited from Aristotle), highlighting how melancholy became a sign of class refinement and moral distinction (46-51), going on to focus on the links between melancholy and sensibility in what became a nerve-oriented society, offering very interesting remarks on gender differences and melancholy as it is considered today throughout this chapter.

In Chapter 2 ("Philosophical Melancholy", 54-82), Richard Terry, drawing attention to the different appreciations of melancholy today and in the eighteenth century from a study of the semantic mutations and instabilities of the passions of joy and sorrow, giftedly explores "the relation of depression to unhappiness" (58), and how philosophy deals with melancholy. To do so, he assesses how eighteenth-century people made sense of their sorrow and coped with it, laying strong emphasis on "an amalgam of philosophical and religious teachings" (65), among them the merits of cheerfulness, the genre of "consolatory advice" (64), the notions of acceptance and fortitude, and the complex and much disputed influence of classical stoicism. The author rounds off his demonstration by showing the way stoics were sometimes treated as hypocritical figures of fun, unable to swallow their own medicine, and by analysing the opposition between valuable sensibility and stoical indifference.

The aim of John Baker in Chapter 3 ("'Strange Contrarys': Figures of Melancholy in Eighteenth-Century Poetry", 83-113) is to identify how poetry expresses and comes to terms with melancholy, taking into account the Graveyard poetry tradition. In this very inspired chapter, John Baker focuses in great detail on the voices, recurrent images, metaphors and figures of the poetry of melancholy, and insists on the contrary approaches to and feelings elicited by depression and expressed by various poets: repulsion, affliction, loss, lack, but also attraction, fascination and creativity. He successfully analyses his choice of poems composed by well- or less well-known melancholy poets of the period to explain that poetry is a genre that "at one describes, expresses and transcends melancholy" (91), thereby also showing how through melancholy the individual is united with his fellow beings.

In Chapter 4, devoted to the study of "Despair, Melancholy and the Novel" (114-41), Stuart Sim assesses the influence of the spiritual autobiography and the pattern of the "conversion narrative" (114) on a brilliant chronological study of novels ranging from Bunyan's Grace Abounding and Pilgrim's Progress to Hogg's Private Memoirs and Confessions of a Justified Sinner, through novels by Defoe, Richardson, Burney, Hays, Henry and Sarah Fielding, Sterne and Godwin. He enlighteningly focuses on the weight religionCalvinism-considered as the "cause or cure" (140) of melancholy-plays on the individual's despair or banishment of despair, and on the devastating influence of patriarchal society on women's melancholy. His conclusion draws deserved attention to 
"the secularization of despair" (139), and to the decline of providentialism, reflected in the novels of the period, as over the long eighteenth century, a shift took place from "a theology-led to a medicine-led conception of depression" (141).

7 Anchored in the triple context of the influence of the genre of the spiritual biography, of the growing interest in the self and of the rise of autobiography typical of the eighteenth century, Leigh Wetherall-Dickson's analysis, in Chapter 5 ("Melancholy, Medicine, Mad Moon and Marriage: Autobiographical Expressions of Depression", 142-69), skilfully tackles four autobiographical accounts of depression-two spiritual narratives and two secular diaries-written by two men and two women belonging to different social classes. The author's aim is to show how the act of writing "gives shape and meaning to an otherwise destabilising experience" (145) in relation to themselves and society. Writing the self enables women to find a voice and make it heard. While "spiritual autobiographies ... depict a shift from a self that has become fractured by suffering to one that emerges whole, cleansed and redeemed", (157), Leigh WetherallDickson makes it clear that the "audit of character" (168) enabled by these autobiographical accounts of depression sometimes fell short of the writers' expectations.

8 In the sixth and last chapter ("Deciphering Difference: A study in Medical Literacy", 170-202), Allan Ingram brilliantly explores "how far were, and are, medical responses actually helping the 'troubled in mind', and ... actually contributing to the problem" (170). Comparing both periods, he explains that doctors today regularly resort to the "readily available, and seductively simple, antidepressant solution" (23), and that depression tends to be treated not on an individual basis, as was commonly the case in the eighteenth century when depressive states were addressed in a spiritual perspective, and most physicians lent a Christian ear to their melancholy patient's plight. In the wake of recent studies and the discovery of the devastating side-effects of depressants, Allan Ingram suggests that our responses to depressive people, too often dictated by the pharmaceutical industry, are inadequate, and should integrate the attention, benevolence, sensitivity and humanity evinced by doctors in the eighteenth century-even if the medicines available then were not always effective-as "the core ... is the relationship between doctor and patient, even before the relation between patient and illness" (187).

9 Taken together, the perspectives developed in each chapter by an authority in the field, buttressed by the various cross-references, enable the reader to get a thorough idea of what it meant to experience melancholy at the time. Offering excellent insight into what the eighteenth century can teach us in terms of treatment of depressive states, it will be of great value not only to eighteenth-century scholars and students, but to all persons with an interest in the workings of the human mind and its disorders. 
INDEX

Mots-clés: autobiographie, autobiographie spirituelle, dépression, folie, génie créatif, médecine, mélancolie, poésie des cimetières, sensibilité, stoïcisme, théorie et pratique médicales

Keywords: autobiography, creative genius, depression, graveyard poetry, madness, medical theory and practice, medicine, melancholy, sensibility, Stoicism, spiritual autobiography

\section{AUTHORS}

\section{HÉLÈNE DACHEZ}

Professeur

Université Toulouse 2 - Le Mirail

h.dachez@wanadoo.fr 